\title{
APPROACH TO THE TREATMENT OF METASTATIC CASTRATION-SENSITIVE PROSTATE CARCINOMA: A SINGLE CENTER EXPERIENCE
}

\section{Huseyin Salih Semiz ${ }^{1}$, Merve Keskinkilic ${ }^{2}$, Halil Ibrahim Ellez ${ }^{2}$, Mehmet Emin Arayici ${ }^{3}$, Aziz Karaoglu ${ }^{1}$}

\author{
${ }^{1}$ Dokuz Eylul University, Institute of Oncology, Department of Medical Oncology, Izmir Turkey \\ ${ }^{2}$ Dokuz Eylul University, Faculty of Medicine, Department of Medical Oncology, Izmir, Turkey \\ ${ }^{3}$ Dokuz Eylul University, Institute of Health Sciences, Department of Preventive Oncology, Izmir, Turkey
}

Corresponding Author: Huseyin Salih Semiz, MD, E-mail: hsalihsemiz@hotmail.com

Received: 14.01.2022; Accepted: 24.01.2022; Available Online Date: 27.01.2022

(C) Copyright 2021 by Dokuz Eylül University, Institute of Health Sciences - Available online at https://dergipark.org.tr/en/pub/jbachs

Cite this article as: Semiz HS, Keskinkilic M, Ellez HI, Arayici ME, Karaoglu A. Approach to the Treatment of Metastatic Castration-Sensitive Prostate Carcinoma: A Single Center Experience. J Basic Clin Health Sci 2022; 6: 296-304.

\begin{abstract}
Objevtive: Prostate cancer is the the second common cancer in men in Turkey. We aimed to share our single center experience on the characteristics of patients with metastatic castration sensitive prostate cancer (mCSPC) and the factors affecting survival.

Material and Methods: In this retrospective cross-sectional study, 280 patients (aged 18 years and older men) who applied with the diagnosis of metastatic prostate carcinoma were screened between January 2007 and December 2020. Sociodemographic and clinicopathological characteristics of the patients were obtained retrospectively from the hospital database. The study variables of the research were included descriptive characteristics of the patients, metastasis sites, treatment approachs, comorbidities of the patients and overall survival (OS) were evaluated. The descriptive statistics, Chi-Square Test, Fisher Exact Test, Kaplan Meier, and Cox Regression models were used as appropriate for the statistical analysis.

Results: A total of 201 patient who applied with the diagnosis of mCSPC were included in this study. The median age of the patients at the time of diagnosis was 68.67 years $(43,97-90,48), 43.56 \%(n=88)$ of the patients were $\geq 70$ years old and $56.43 \%(n=114)$ were under 70 years of age. The median follow-up time was 55.5 months, and the median OS was found to be 34.93 months (27.90-41.96). $34.7 \%$ of the patients were still alive at the time of date cutoff. The median OS of the patients was found to be significantly lower in individuals $\geq 70$ years old than under 70 years of age $(p=0.032)$. According to the LATITUDE study the median OS of the high-risk group (26.56 months) was statistically significantly lower than in the low-risk group (44.83 months). When the patients were evaluated in terms of disease volume according to CHAARTED, it was found that the median OS of the patient group with high-volume disease (29.03 months) was statistically significantly lower than the group with low-volume disease (46.80 months) $(p=0.001)$.

Conclusion: In this study, it was shown that being over 70 years old, a low BMI, high volume disease defined as in the CHAARTED trial, and high risk disease defined as in the LATITUDE trial had a negative impact on survival of patients with $\mathrm{mCSPC}$.
\end{abstract}

Keywords: prostat cancer, survival, castration, elderly

\section{INTRODUCTION}

Prostate cancer is the most common cancer in men worldwide, with an estimated 1,600,000 cases and
366,000 deaths annually (1). Affects $11 \%$ of men in the United States, and the risk of developing it increases with age (2). According to GLOBOCAN 
2020 data, prostate cancer is the second common cancer $(\% 14,6)$ and the second leading cause of death from cancer among men in Turkey (3). Males over the age of 65 account for around 6 out of every 10 cases, whereas men under the age of 40 are extremely rare. Men are diagnosed at an average age of 66 . When all stages are included, the five-year survival rate is $98 \%$, while the five-year survival rate is $30 \%$ in case of distant metastasis (4). Surgery, radiotherapy and testosterone suppressive treatments, also known as androgen deprivation therapy (ADT), are used in the treatment of localized prostate carcinoma. Unfortunately, despite all these treatments, the transition of some of the patients to the metastatic stage cannot be prevented. Patients who relapse after radical treatments are defined as castration sensitive prostate cancer (CSPC). Patients who progress while receiving adjuvant "adrogen deprivation therapy" are defined as "castration resistant prostate cancer (CRPC)". In the castrationsensitive non-metastatic stage, observation or androgen deprivation therapy can be recommended, while in the metastatic stage, ADT alone for patients who can not tolerete combined systemic therapies, abiraterone asetate (AA), enzalutamide $(E)$, docetaxel (T), apalutamide (APA) can be recommended. EBRT for the primary tumor in lowvolume disease can be recommended. Treatment options in CRPC include anti-androgen therapies (AA, oteronel, seviteronel, galaterone), androgen receptor blockers (E, APA, darolutamide), taxanes ( $T$, cabazitaxel), radionuclide therapies (Lu-177, Ra223). immunotherapies (Spilucel T, pembrolizumab, durvalumab, ipilimumab), PARP inhibitors (olaparib) and multikinase inhibitors (cabozantinib). Bisphosphonate and denosumab can be used as bone-sparing treatment in patients with bone metastases (5). Among the factors affecting the treatment decision; parameters such as the patient's age, comorbidities, ECOG performance score, tumor burden, natural history of the disease in the patient, and Gleason score (GS). Aim of this study is to determine the demographic, clinicopathological and treatment characteristics of prostate cancer patients, as well as to reveal the effects of these characteristics on survival as a single center experience.

\section{MATERIAL AND METHODS}

This retrospective cross-sectional study was conducted to 280 male patients (aged 18 years and older) who applied with the diagnosis of metastatic prostate carcinoma, between January 2007 and December 2020. After excluding 79 patients with missing data and the presence of a second primary malignancy, a total of 201 patients were included in the study.

Inclusion criteria were being a male patient aged 18 years and over and diagnosis of prostate carcinoma at stage IV as well as patients who have received at least one line of therapy for prostate carcinoma, including ADT. Exclusion criteria were inability to access patient data from the hospital database, having a histology other than prostate adenocarcinoma, castration resistant patients and presence of synchronous malignancy (except carcinomas in situ, bladder noninvasive carcinomas, non-melanoma skin cancers).

The dependent variables of the research were progression-free survival, time to castration resistance, time to skeleton related events and overall survival (OS). The independent variables of the research were descriptive and clinicopathologic characteristics of the patients, site of metastasis, GS, disease volume, chemohormonal agents, age and comorbidities. Sociodemographic and clinicopathological characteristics of the patients were obtained retrospectively from the hospital database.

For the statistical analysis, descriptive statistics (mean \pm standard deviation, percent $(\%)$ ), the ChiSquare Test and Fisher Exact test were used as appropriate. Survival analysis was evaluated with Kaplan Meier. The level of statistical significance was set as $p<0.05$. All data analysis was performed using the Statistical Package for Social Science (SPSS) version 24.0. Ethical approval for this study was obtained from the Tepecik Training and Research Hospital Ethics Committee (Date of approval: 23.12.2020; Decision number 2020/14- 59).

\section{RESULTS}

A total of 201 patients who applied to our oncology clinic with the diagnosis of metastatic castration sensitive prostate carcinoma were included in this study. The descriptive and clinicopathologic characteristics of the study (age, comorbidity, body mass index (BMI), stage, disease volume/risk status and histopathological features of the patient population) were presented in Table 1 and Table 2, respectively. The factors affecting the OS of the patients were evaluated according to clinical, histopathological, volume/risk, and treatment given. 
Table 1. Sociodemographic and Clinicopathologic Caracteristics of Patients

\begin{tabular}{|c|c|}
\hline Characteristics & n (\%) \\
\hline $\begin{array}{l}\text { Comorbidity } \\
\text { None } \\
\text { One } \\
\text { Two or more }\end{array}$ & $\begin{array}{l}95(47 \%) \\
65(32,2 \%) \\
42(20,8 \%)\end{array}$ \\
\hline $\begin{array}{l}\text { Age Distribution } \\
\quad<70 \text { years } \\
\geq 70 \text { years }\end{array}$ & $\begin{array}{l}114(56,4 \%) \\
88(43,6 \%)\end{array}$ \\
\hline $\begin{array}{l}\text { BMI } \\
\qquad 18,5 \\
18,5-24,9 \\
25-29,9 \\
>30\end{array}$ & $\begin{array}{l}2(1 \%) \\
62(30,7 \%) \\
103(51 \%) \\
35(17,3 \%)\end{array}$ \\
\hline $\begin{array}{l}\text { ISUP Grade } \\
1 \\
2 \\
3 \\
4 \\
5 \\
\text { Unknown }\end{array}$ & $\begin{array}{l}4(2 \%) \\
21(10,4 \%) \\
34(16,8 \%) \\
41(20,3 \%) \\
92(45,5 \%) \\
10(5 \%)\end{array}$ \\
\hline $\begin{array}{l}\text { Stage } \\
\text { M0 } \\
\text { M1a } \\
\text { M1b } \\
\text { M1c } \\
\text { Mx } \\
\text { Unknown }\end{array}$ & $\begin{array}{l}2(1 \%) \\
20(9,9 \%) \\
138(68,3 \%) \\
28(13,9 \%) \\
5(0,5 \%) \\
13(6,4 \%)\end{array}$ \\
\hline $\begin{array}{l}\text { CHAARTED Volume } \\
\text { Low Volume } \\
\text { High Volume } \\
\text { Unknown }\end{array}$ & $\begin{array}{l}59(29,2 \%) \\
141(69,8 \%) \\
2(1 \%)\end{array}$ \\
\hline $\begin{array}{l}\text { LATITUDE Rısk } \\
\text { Low Risk } \\
\text { High Risk } \\
\text { Unknown }\end{array}$ & $\begin{array}{l}97(48 \%) \\
103(51 \%) \\
1(1 \%)\end{array}$ \\
\hline $\begin{array}{l}\text { Skeleton } \\
\text { Events } \\
\quad \text { No } \\
\text { Yes }\end{array}$ & $\begin{array}{l}152(75,2 \%) \\
50(24,8 \%)\end{array}$ \\
\hline
\end{tabular}

The median age of the patients at the time of diagnosis was 68.67 years $(43,97-90,48), 43.56 \%$ $(n=88)$ of the patients were $\geq 70$ years old and $56.43 \%(n=114)$ were under 70 years of age. The median follow-up time was 55.5 months, and the median OS was found to be 34.93 months (27.9041.96) (Figure 1). $34.7 \%$ of the patients were still alive at the time of date cut-off. At the time of data cut-off, castration resistance developed in 151 patients (75.1\%) and not yet developed in 50 patients $(24.9 \%)$. The median time to develop castration resistance was 19 months (0-124 months).

The OS of the patients was evaluated according to age and presented in Figure 2. The median time to castration resistance development was statistically significantly longer in patients younger than 70 years compared to patients 70 years of age and over (24.7 vs 20 months, $p=0.046$ ). The median os of the patients under 70 years and $\geq 70$ years old were 39.40 (95\% Cl; 31.07-47.72) and $27.86(95 \% \mathrm{Cl} ; 19.50$ $36.22)$, respectively. The median OS of the patients was found to be significantly lower in patients $\geq 70$ years old than under 70 years of age $(p=0.032)$. When the median OS was evaluated according to $\mathrm{BMI}$, it was interestingly found that patients with higher BMI had longer survival than patients with lower BMI $(p<0.001) \quad$ (Figure 3$)$. Patients were separated into two risk groups (high-risk group and low risk group) according to the LATITUDE study. The median OS of the high-risk group (26.56 months), which was $51 \%$ of all patients, was statistically significantly lower than in the low-risk group (44.83 months) $(p<0.001)$ (Figure 4). When the patients were evaluated in terms of disease volume according to CHAARTED (high volume and lowvolume disease), it was found that the median OS of the patient group with high-volume disease (29.03 months), which constitutes $69.8 \%$ of the research group, was statistically significantly lower than the group with low-volume disease (46.80 months) $(p=0.001)$ (Figure 5). In addition, the effects of chemotherapy, orchiectomy, bicalutamide use, comorbidity and ISUP grade on OS in CSPC were evaluated and summarized in Table 3 . It was observed that these parameters did not have a statistically significant effect on survival.

Patients at the CSPC stage were separated into lowrisk and high-risk groups according to the risk classification defined in the LATITUDE study and lowvolume and high-volume groups according to the disease volume criteria defined in the CHAARTED study. The effects of systemic treatments (chemotherapy, new generation hormonal agents) on these groups were examined and presented in Table 4. When the median OS of the patients in the low-risk group were compared, altough the median OS of those who received chemotherapy $(n=68 \quad(70.8 \%))$ were longer than who not received chemotherapy $(n=28(29.1 \%))$, it was no statistically significant $(p>0.05)$. When we examined our patients according to the LATITUDE study, there was no statistically significant difference in terms of OS in the high-risk group who received chemohormonal therapy ( $\mathrm{n}: 65$ [65.6\%]) and who did not receive chemohormonal therapy (35.7 months). When we examined our 
Table 2. Treatment Characteristics

\begin{tabular}{|c|c|}
\hline $\begin{array}{l}\text { Surgery Status } \\
\text { No } \\
\text { Radical } \\
\text { Prostatectomy }\end{array}$ & $\begin{array}{l}175(86,6 \%) \\
27(13,4 \%)\end{array}$ \\
\hline $\begin{array}{l}\text { Radiotherapy } \\
\text { No radiotherapy } \\
\text { Adjuvant } \\
\text { Definitive } \\
\text { Palliative } \\
\text { Definitive +Palliative } \\
\text { Adjuvant + Palliative } \\
\text { Salvage }\end{array}$ & $\begin{array}{l}98(48,5 \%) \\
4(2 \%) \\
19(9,4 \%) \\
75(37,1 \%) \\
3(1,5 \%) \\
1(0,5 \%) \\
2(1 \%)\end{array}$ \\
\hline $\begin{array}{l}\text { Orchiectomy } \\
\text { Yes } \\
\text { No }\end{array}$ & $\begin{array}{l}36(17,8 \%) \\
166(82,2 \%)\end{array}$ \\
\hline $\begin{array}{l}\text { Bicalutamid } \\
\text { No or only to avoid flare } \\
\text { Present }\end{array}$ & $\begin{array}{l}110(54,5 \%) \\
92(45,5 \%)\end{array}$ \\
\hline $\begin{array}{l}\text { Bone sparing therapy in } \\
\text { the CSPC stage } \\
\text { No } \\
\text { Zoledronic acid } \\
\text { Unknown }\end{array}$ & $\begin{array}{l}94(46,5 \%) \\
107(53 \%) \\
1(0,5 \%)\end{array}$ \\
\hline $\begin{array}{l}\text { Chemohormonal therapy } \\
\text { in CSPC } \\
\text { No } \\
\text { Docetaxel }(q 3 w) \\
\text { Docetaxel }(q 2 w) \\
\text { Enzalutamide } \\
\text { Abiraterone }\end{array}$ & $\begin{array}{l}135(\% 68,5) \\
56(\% 27,2) \\
3(\% 1,5) \\
2(\% 1) \\
1(\% 0,5)\end{array}$ \\
\hline
\end{tabular}

patients according to the CHAARTED study, the rate of patients who received chemotherapy was $64.96 \%$ versus $75.89 \%$ in high-volume and low-volume disease. However, there was no statistically significant effect on survival of chemohormonal therapy regardless of volume status $(p>0.05)$.

Disease volume and risk discordance were evaluated according to the CHAARTED and LATITUDE studies and presented in Table 5. According to the CHAARTED criteria, $27.7 \%$ of our patients in the high-volume disease group were in the low-risk group according to the LATITUDE criteria. On the other hand, $1.7 \%$ of our patients in the high-risk group according to the LATITUDE criteria were in the lowvolume disease group according to the CHAARTED criteria $(p<0.001)$.

\section{DISCUSSION}

In this study, we determined the demographic, clinicopathologic and treatment characteristics of prostate cancer patients and the effects of these characteristics on survival. In a trial conducted by Zorlu $\mathrm{F}$ et al the median age at the time of diagnosis was 68 years in patients with prostate cancer who living in Turkey (6). In our study, the median age was 68.67 years, which was consistent with our country's data. In our study, the number of patients over the age of 70 was $43.6 \%$. After a median follow-up period of 55,5 months, $34.7 \%$ of the metastatic patients were still alive. Prostate cancer is the cancer of the geriatric age group, and the number of comorbidities increases with age. In a study conducted by Jefferson et al, in patients with prostate cancer, $51 \%$ of the patients had at least 1 comorbidity (7). $53 \%$ of the patients in our study had at least 1 comorbidity, which was consistent with the literature. Clinical stage according to American Joint Committee on Cancer (AJCC), GS/grade group according to biopsy result, serum PSA value, imaging and genomic profile form the basis of initial treatment decisions in a patient diagnosed with prostate cancer (8). "The Gleason grades for the two most prevalent differentiation patterns are combined to create the GS, and GS is now incorporated into the newly adopted grade group system (9). In the grade group system, tumors are separated into five categories based upon the primary and secondary Gleason pattern: Grade group 1 (GS $3+3$ ), Grade group 2 (GS $3+4$ ), Grade group 3 (GS $4+3$ ), Grade group 4 (GS 4+4, 3+5, or $5+3$ ), Grade group 5 (GS $4+5,5+4$, or $5+5$ )." As the GS increases, the prognosis of the disease worsens. In our study grade group 4 and 5 was $65,8 \%$ of patient populations. Therefore, it can be said that the patients included in our study represent a poor prognostic group. In a study that included 5100 patients diagnosed with prostate cancer between the ages of 70 and $80,17.5 \%$ of the patients had a GS of 8 or higher. However, non-metastatic patients were also included in this study, and therefore, patients with a high GS were found to be less than in our study. Indirectly, it can be concluded that the GS is higher in metastatic patients (10). Bone metastasis is the most common metastasis in prostate cancer, and in a large population-based study where the incidence of bone metastasis in cancer patients was investigated (11), the rate of bone metastasis in patients with prostate cancer was found to be $84.7 \%$. In our study, the rate of bone metastasis was $68.3 \%$, although it was less common than this study. The mainstay of treatment for $\mathrm{mPC}$ has been to achieve castrate levels of testosterone in patients through medical ADT (LHRH agonists or antagonists) or surgical ADT (bilateral orchiectomy). In a retrospective study conducted on national cancer registries, that investigating castration methods in patients with prostate cancer, it 
Table 3. Characteristics Evaluated as an Effect on Survival

\begin{tabular}{|c|c|c|c|c|}
\hline Characteristics & n (\%) & $\begin{array}{l}\text { Median OS } \\
(\mathrm{mo})\end{array}$ & $\% 95 \mathrm{Cl}$ & P Value \\
\hline $\begin{array}{l}\text { Age } \\
\quad<70 \text { years } \\
\geq 70 \text { years }\end{array}$ & $\begin{array}{l}114(56,4 \%) \\
88(43,6 \%)\end{array}$ & $\begin{array}{l}39,40 \\
27,86\end{array}$ & $\begin{array}{l}31,07-47,72 \\
19,50-36,22\end{array}$ & $P=0,032$ \\
\hline 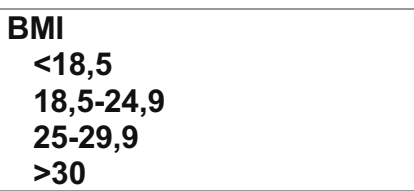 & $\begin{array}{l}2(1 \%) \\
62(30,7 \%) \\
103(51 \%) \\
35(17,3 \%)\end{array}$ & $\begin{array}{l}\text { Not reached } \\
26,56 \\
43,96 \\
38,70\end{array}$ & $\begin{array}{c}21,57-31,56 \\
34,54-53,38 \\
30,28-47,11\end{array}$ & $P=<0,001$ \\
\hline $\begin{array}{l}\text { Chemohormonal therapy } \\
\text { Yes } \\
\text { No }\end{array}$ & $\begin{array}{l}62(31,5 \%) \\
135(68,5 \%)\end{array}$ & $\begin{array}{l}36,23 \\
35,96\end{array}$ & $\begin{array}{l}26,34-46,12 \\
26,53-45,39\end{array}$ & $P=0,770$ \\
\hline $\begin{array}{l}\text { Orchiectomy } \\
\text { Yes } \\
\text { No }\end{array}$ & $\begin{array}{l}36(17,8 \%) \\
166(82,2 \%)\end{array}$ & $\begin{array}{l}31,93 \\
35,70\end{array}$ & $\begin{array}{l}19,74-44,12 \\
27,70-43,69\end{array}$ & $P=0,949$ \\
\hline $\begin{array}{l}\text { Bicalutamid } \\
\text { No } \\
\text { Yes }\end{array}$ & $\begin{array}{l}110(54,5 \%) \\
92(45,5 \%)\end{array}$ & $\begin{array}{l}32,30 \\
35,96\end{array}$ & $\begin{array}{l}24,21-40,38 \\
22,69-49,24\end{array}$ & $P=0,220$ \\
\hline $\begin{array}{l}\text { Comorbidity } \\
\text { None } \\
\text { One } \\
\text { Two or more }\end{array}$ & $\begin{array}{l}95(47 \%) \\
65(32,2 \%) \\
42(20,8 \%)\end{array}$ & $\begin{array}{l}29,13 \\
42,36 \\
32,30\end{array}$ & $\begin{array}{l}20,59-37,66 \\
36,80-47,92 \\
23,91-40,68\end{array}$ & $P=0,746$ \\
\hline $\begin{array}{c}\text { ISUP Grade } \\
1 \\
2 \\
3 \\
4 \\
5\end{array}$ & $\begin{array}{l}4(2 \%) \\
21(10,4 \%) \\
34(16,8 \%) \\
41(20,3, \%) \\
92(45,5 \%)\end{array}$ & $\begin{array}{l}\text { Not reached } \\
54,20 \\
35,96 \\
38,70 \\
29,03\end{array}$ & $\begin{array}{l}42,51-65,88 \\
17,85-54,34 \\
32,09-45,30 \\
20,62-37,44\end{array}$ & $P=0,089$ \\
\hline $\begin{array}{l}\text { LATITUDE Rısk Status } \\
\text { Low Risk } \\
\text { High Risk }\end{array}$ & $\begin{array}{l}97(48 \%) \\
103(51 \%)\end{array}$ & $\begin{array}{l}44,83 \\
26,56\end{array}$ & $\begin{array}{l}33,94-55,72 \\
23,18-29,94\end{array}$ & $P=<0,001$ \\
\hline $\begin{array}{l}\text { CHAARTED Volume Status } \\
\text { Low Volume } \\
\text { High Volume }\end{array}$ & $\begin{array}{l}59(29,2 \%) \\
141(69,8 \%)\end{array}$ & $\begin{array}{l}46,80 \\
29,03\end{array}$ & $\begin{array}{l}35,81-57,78 \\
34,27-33,79\end{array}$ & $P=0,001$ \\
\hline
\end{tabular}

was seen that orchiectomy was performed in $5.4 \%$ of the patients (12), and this rate was higher with $17.8 \%$ in our study. The low socioeconomic status of cancer patients living in the region where our oncology clinic is may have caused this. Because it is known that as the socioeconomic level decreases, the preference for orchiectomy as a castration method increases (13). Zoledronic acid treatment is not recommended in CSPC with bone metastases after the CALGB 202 trial in 2014 (14), which showed that the use of zoledronic acid therapy in patients with bone metastases in the castration-sensitive stage did not reduce SRE. In our study, the use of zoledronic acid in the CSPC stage was $53 \%$, and the rate of bonepreserving treatment in the CRPC stage was $62.6 \%$. Since this rate was high in the castration-sensitive stage, it was thought that 75 patients in our patient group were diagnosed before 2014. At the CSPC stage, $31.5 \%$ of our patients received chemotherapy. In our study, we did not see a significant effect of systemic chemotherapy on survival at the CSPC stage. In the GETUG-AFU 15 study conducted by Gravis $G$ et al. in 2013, it was shown that adding docetaxel to ADT at the CSPC stage had no survival benefit (15). However, contrary results were obtained later in the STAMPEDE arm $\mathrm{C}$ and the CHAARTED trial (16). In the CHAARTED trial published in 2015, it was shown that chemotherapy contributes to survival in CSPC (17). In the light of these data, chemotherapy has become the primary reason for preference for patients diagnosed after 2015, which is necessary. $14.5 \%$ of patients received 
Table 4. Effect of Chemotherapy on Survival by Volume and Risk Status

\begin{tabular}{|c|c|c|c|c|}
\hline Characteristics & $\%(n)$ & Median (mo) & $\% 95 \mathrm{Cl}$ & P Value \\
\hline $\begin{array}{l}\text { CSPC LATITUDE Rısk } \\
\text { Low Risk } \\
\text { Not Received Chemotherapy } \\
\text { Received Chemotherapy } \\
\text { High Risk } \\
\text { Not Received Chemotherapy } \\
\text { Received Chemotherapy }\end{array}$ & $\begin{array}{l}28(29,1 \%) \\
68(70,8 \%) \\
\\
34(34,3 \%) \\
65(65,6 \%)\end{array}$ & $\begin{array}{l}37,03 \mathrm{mo} \\
46,23 \mathrm{mo} \\
35,70 \mathrm{mo} \\
26,56 \mathrm{mo}\end{array}$ & $\begin{array}{l}13,18-60,87 \\
34,87-57,59 \\
20,48-50,92 \\
22,52-30,60\end{array}$ & $P=0,636$ \\
\hline $\begin{array}{l}\text { CSPC CHAARTED Volume } \\
\text { Low Volume } \\
\text { Not Received Chemotherapy } \\
\text { Received Chemotherapy } \\
\text { High Volume } \\
\text { Not Received Chemotherapy } \\
\text { Received Chemotherapy }\end{array}$ & $\begin{array}{l}14(24,1 \%) \\
44(75,9 \%) \\
\\
48(35 \%) \\
89(65 \%)\end{array}$ & $\begin{array}{l}\text { Not reached } \\
46,23 \\
29,13 \\
29,03\end{array}$ & $\begin{array}{l}42,20-50,26 \\
21,57-36,48 \\
22,60-35,66\end{array}$ & $P=0,511$ \\
\hline
\end{tabular}

Table 5. Disease Status Concordance According to CHAARTED and LATITUDE

\begin{tabular}{|l|l|l|l|l|l|}
\hline & \multicolumn{2}{|l|}{} & \multicolumn{2}{l|}{ Risk according to LATITUDE } & \multirow{2}{*}{ P Value } \\
\cline { 3 - 5 } & \multicolumn{2}{|l|}{} & Low Risk & High Risk & \\
\cline { 3 - 5 } $\begin{array}{l}\text { Volume } \\
\text { according } \\
\text { CHAARTED }\end{array}$ \\
\cline { 3 - 5 }
\end{tabular}

chemotherapy before 2015 for CSPC. Administration of chemotherapy for CSPC in patients diagnosed after 2015 has been increased with the CHAARTED (44.9\% of patients). In whole study population, the rate of chemotherapy in low-volume CSPC was $24.1 \%$, while in high-volume disease was $35 \%$.

Considering the factors that have an effect on survival in our study, it was seen that advanced age, low BMI, high volume and high risk disease had a statistically significant poor prognostic effect on survival. When we look at the literature, contrary to the result of our study, there are studies showing that prostate cancer recurrence and mortality increase as the degree of obesity increases (18). While there is a study showing that patients diagnosed with prostate cancer under the age of 40 have a lower survival rate and the tumor is more aggressive than the elderly group (19), there is also a study showing that those aged 49 and younger have a 10-year survival rate higher than those aged 80 and over (20). Both high-risk patients in the LATITUDE trial (21) and patients with highvolume disease in the CHAARTED trial (17) had a shorter survival time, and the data in our study were consistent with the results of these two study. The CHAARTED and LATITUDE trials demonstrated a prolonged OS for metastatic hormone-naïve prostate cancer (mCSPC) patients who receive up-front docetaxel or abiraterone acetate. These studies used their own risk criteria: CHAARTED trial defined highand low-volume diseases and LATITUDE trial targeting a high-risk disease. In a study of the Japanese population, both the high-volume patient ratio according to CHAARTED and high-risk patients rate according to LATITUDE $57.7 \%$, high volume according to CHAARTED low-risk patients rate according to LATITUDE $8.8 \%$, high-risk patients rate according to LATITUDE low volume patients according to CHAARTED as $12.8 \%$ was found (22). In another study, the rate of patients with high volume/high risk according to both studies were $44.8 \%$, the rate of patients with high risk compared to CHAARTED but low risk compared to LATITUDE was $10 \%$, and the rate of patients with high risk compared to LATITUDE and CHAARTED was $10 \%$. The rate of low-volume patients was $7.7 \%$ (23). In our study, the rate of patients with high volume according to 


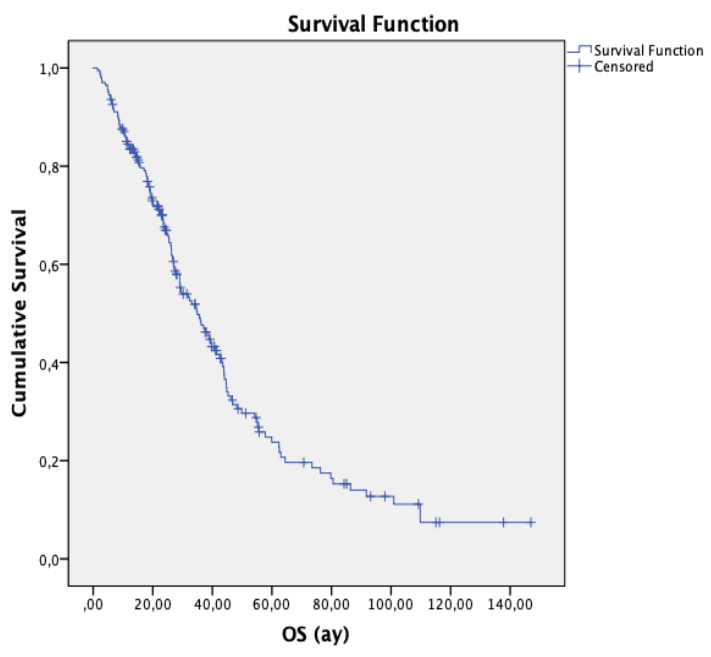

Figure 1. Median Overall Survival

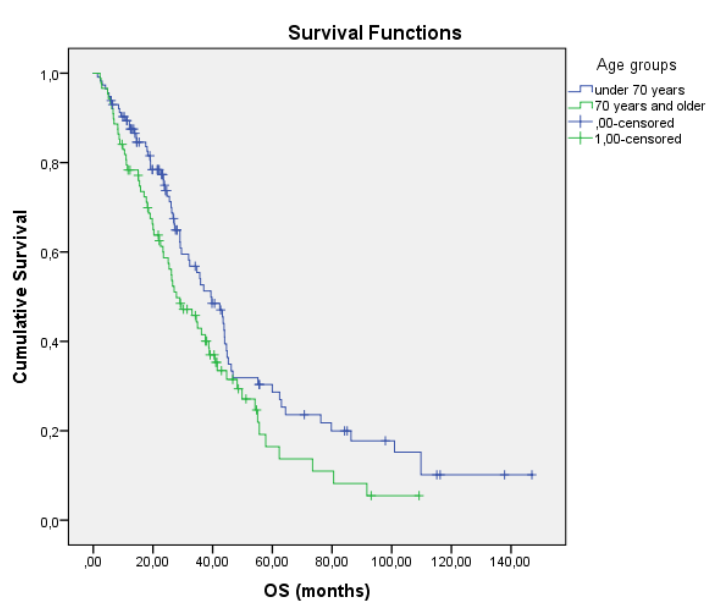

Figure 2. Overall Survival According to Age

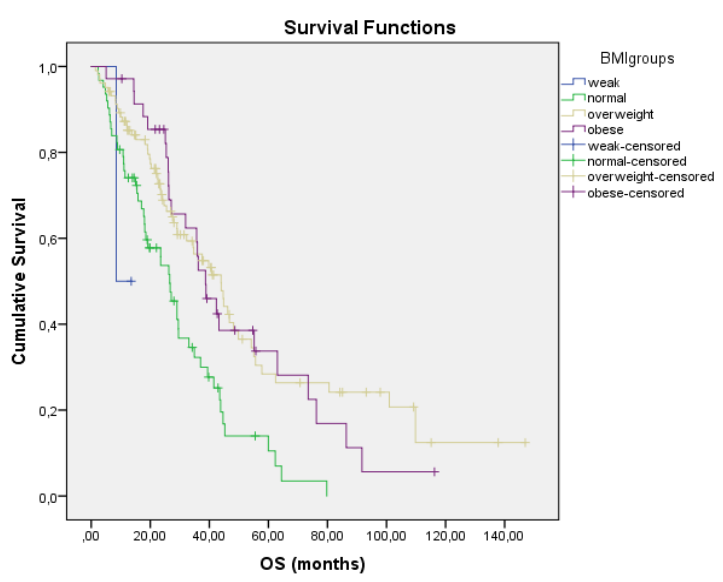

Figure 3. Overall Survival According to BMI

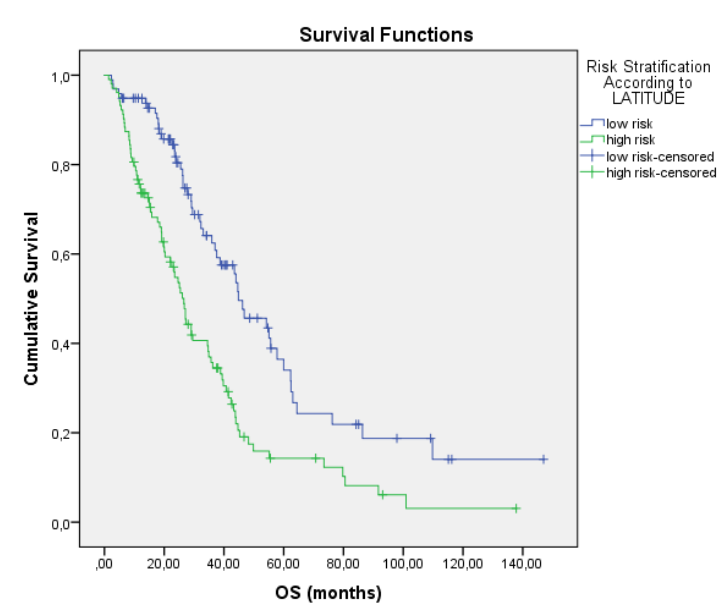

Figure 4. Overall Survival According to LATITUDE

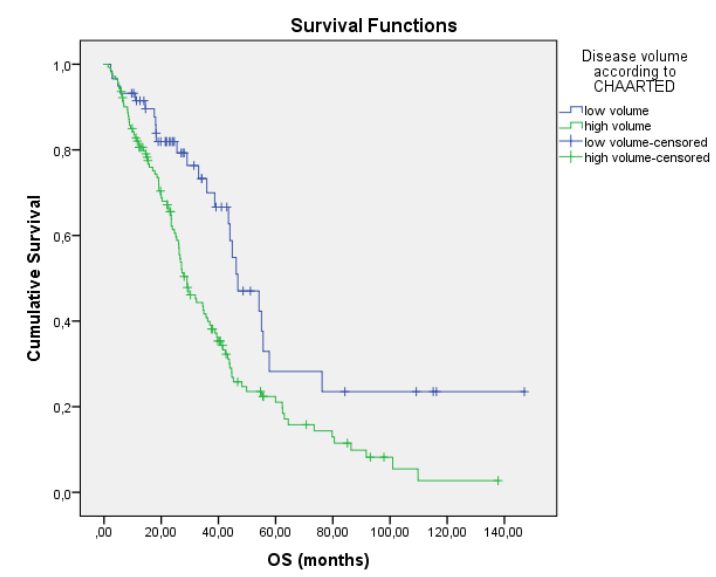

Figure 5. Overall Survival According to CHAARTED

CHAARTED and high risk according to LATITUDE is $72.3 \%$, the rate of patients with low risk according to high volume LATITUDE according to CHAARTED is $27.7 \%$, which is higher than the literature was found. The rate of high-risk patients according to LATITUDE with low volume compared to CHAARTED was $1.7 \%$, which was found to be low compared to the literature. As it can be understood from here, it is seen that the discordance between LATITUDE and CHAARTED varies according to studies. As a result, in this study in which data from a single center were shared, some of our results were compatible with the literature, but some of our results had contradictory results with the literature. It is thought that this discrepancy may be due to the smaller number of patients and information obtained from a single center compared to the 
literature, and that recent studies that lead to changes in treatment may explain these differences.

\section{CONCLUSION}

With the development of new treatment modalities, survival has reached a very good level compared to previous years, but metastatic prostate carcinoma still remains a deadly disease. Many randomized phase 3 studies have demonstrated the survival benefit of adding systemic therapies (docetaxel, abiraterone, enzalutamide) to ADT during the CSPC phase. However, patients with a diagnosis of MCSPC that we encounter in clinical practice may have worse prognostic features, a much higher number of comorbidities, and a shorter life expectancy than patients entering these clinical trials. However, it is an undeniable fact that all mCSPC patients with appropriate performance status should be given systemic treatment together with ADT.

Author contrubitions: Concept- H.S.S, AK; Design- H.S.S, AK; Supervision- A.K.; Materials- M.E.A.; Data collection \&/or processing- M.K., H.I.E.; Analysis and interpretation- M.E.A., H.S.S.; Literature search- M.K., H.I.E.; Writing- H.S.S., M.E.A., M.K.; Critical review- A.K., M.E.A.

Conflict of Interest: None.

Ethical Approval: Ethical approval for this study was obtained from the Tepecik Training and Research Hospital Ethics Committee (Date of approval: 23.12.2020; Decision number 2020/14- 59).

Funding: None.

Peer-review: Externally peer-reviewed.

\section{REFERENCES}

1. Global Burden of Disease Cancer Collaboration, Fitzmaurice C, Allen C, et al. Global, Regional, and National Cancer Incidence, Mortality, Years of Life Lost, Years Lived With Disability, and Disability-Adjusted Life-years for 32 Cancer Groups, 1990 to 2015: A Systematic Analysis for the Global Burden of Disease Study [published correction appears in JAMA Oncol. 2017 Mar 1;3(3):418]. JAMA Oncol. 2017;3(4):524-548.

2. Viale PH. The American Cancer Society's Facts \& Figures: 2020 Edition. J Adv Pract Oncol.2020;11(2):135

136. doi:10.6004/jadpro.2020.11.2.1. The Global Cancer Observatory - March, 2021.

3. Sung H, Ferlay J, Siegel RL, et al. Global Cancer Statistics 2020: Turkey Fact Sheets. Avaliable from:https://efaidnbmnnnibpcajpcglclefindmkaj/vi ewer.html?pdfurl=https $\% 3 \mathrm{~A} \% 2 \mathrm{~F} \% 2 \mathrm{Fgco}$.iarc.fr $\% 2$ Ftoday $\% 2$ Fdata\%2Ffactsheets $\% 2 F$ populatio
ns\%2F792-turkey-fact-

sheets. pdf \&clen $=340028 \&$ chunk=true. Accessed on 12 JAN 2022.

4. National Comprehensive Cancer Network. Prostate Cancer (Version 2.2022). http://www.nccn.org/professionals/physi cian_gls/pdf/prostate.pdf

5. Zorlu F, Zorlu R, Divrik RT, Eser S, Yorukoglu K. Prostate cancer incidence in Turkey: an epidemiological study. Asian Pac J Cancer Prev. 2014; 15(21):9125-9130.

6. Jefferson M, Drake RR, Lilly M, Savage SJ, Tucker Price S, Hughes Halbert C. Comorbidities in a Retrospective Cohort of Prostate Cancer Patients. Ethn Dis. 2020;30(Suppl 1):185-192. Published 2020 Apr 2. doi:10.18865/ed.30.S1.185

7. Kasivisvanathan V, Rannikko AS, Borghi M, et al. MRI-Targeted or Standard Biopsy for ProstateCancer Diagnosis. $N$ Engl J Med. 2018;378(19):1767-1777.

8. Epstein JI, Zelefsky MJ, Sjoberg DD, et al. A Contemporary Prostate Cancer Grading System: A Validated Alternative to the Gleason Score. Eur Urol. 2016;69(3):428-435.

9. Shah N, loffe V. Frequency of Gleason score 7 to 10 in 5100 elderly prostate cancer patients. Rev Urol. 2016;18(4):181-187.

10. Huang JF, Shen J, Li X, et al. Incidence of patients with bone metastases at diagnosis of solid tumors in adults: a large population-based study. Ann Trans/ Med. 2020;8(7):482.

11. Weiner AB, Cohen JE, DeLancey JO, Schaeffer EM, Auffenberg GB. Surgical versus Medical Castration for Metastatic Prostate Cancer: Use and Overall Survival in a National Cohort. J Urol. 2020;203(5):933-939.

12. Smith MR, Halabi S, Ryan CJ, et al. Randomized controlled trial of early zoledronic acid in men with castration-sensitive prostate cancer and bone metastases: results of CALGB 90202 (alliance). $J$ Clin Oncol. 2014;32(11):1143-1150.

13. Borno HT, Lichtensztajn DY, Gomez SL, Palmer NR, Ryan CJ. Differential use of medical versus surgical androgen deprivation therapy for patients with metastatic prostate cancer. Cancer. 2019;125(3):453-462.

14. George DJ, Sartor O, Miller K, et al. Treatment Patterns and Outcomes in Patients With Metastatic Castration-resistant Prostate Cancer in a Real-world Clinical Practice Setting in the 
United States. Clin Genitourin Cancer. 2020;18(4):284-294.

15. Gravis G, Fizazi K, Joly F, et al. Androgendeprivation therapy alone or with docetaxel in non-castrate metastatic prostate cancer (GETUG-AFU 15): a randomised, open-label, phase 3 trial. Lancet Oncol. 2013;14(2):149-158.

16. James ND, Sydes MR, Clarke NW, et al. Addition of docetaxel, zoledronic acid, or both to first-line long-term hormone therapy in prostate cancer (STAMPEDE): survival results from an adaptive, multiarm, multistage, platform randomised controlled trial. Lancet. 2016;387(10024):11631177.

17. Sweeney CJ, Chen $\mathrm{YH}$, Carducci $M$, et al. Chemohormonal Therapy in Metastatic Hormone-Sensitive Prostate Cancer. N Engl J Med. 2015;373(8):737-746.

18. Cao Y, Ma J. Body mass index, prostate cancerspecific mortality, and biochemical recurrence: a systematic review and meta-analysis. Cancer Prev Res (Phila). 2011;4(4):486-501.

19. Bleyer A, Spreafico F, Barr R. Prostate cancer in young men: An emerging young adult and older adolescent challenge. Cancer. 2020;126(1):4657.

20. Siegel DA, O'Neil ME, Richards TB, Dowling NF, Weir HK. Prostate Cancer Incidence and Survival, by Stage and Race/Ethnicity - United States, 2001-2017. MMWR Morb Mortal Wkly Rep. 2020;69(41):1473-1480.

21. Fizazi K, Tran N, Fein L, et al. Abiraterone plus Prednisone in Metastatic, Castration-Sensitive Prostate Cancer. $N$ Engl J Med. 2017;377(4):352-360.

22. Kawahara T, Yoneyama $S$, Ohno $Y$, et al. Prognostic Value of the LATITUDE and CHAARTED Risk Criteria for Predicting the Survival of Men with Bone Metastatic HormoneNaïve Prostate Cancer Treated with Combined Androgen Blockade Therapy: Real-World Data from a Japanese Multi-Institutional Study. Biomed Res Int. 2020;2020:7804932.

23. Kawahara T, Yoneyama S, Ohno Y, et al. Prognostic Value of the LATITUDE and CHAARTED Risk Criteria for Predicting the Survival of Men with Bone Metastatic HormoneNaïve Prostate Cancer Treated with Combined Androgen Blockade Therapy: Real-World Data from a Japanese Multi-Institutional Study. Biomed Res Int. 2020;2020:7804932. 